\title{
Banka Çalışanlarında İşe Yabancılaşma, İş Doyumu Ve Tükenmişlik Arasındaki İlişki
}

\author{
DOI: 10.26466/opus.821059
}

*

\author{
Kasim Kaya * \\ * Dr.Öğr.Üyesi, Harran Üniversitesi, İ̈BF, İşletme Bölümü \\ E-Posta: kkaya@harran.edu.tr \\ ORCID: $\quad$ 0000-0001-8942-4659

\section{Öz}

İse yabancılaşma, bireyin çalıştığı örgütte kariyer, ücret, üstleri tarafindan tanınmama, teknolojinin artışıyla yaptığı işi anlayamama ve sık sık görev değiişikliği ile uyum sorunu yaşaması gibi çeşitli sebeplerden dolayı işine karşı bıkkınlık, isteksizlik, hayal kırıklı̆̆ı hissetmesidir. İş doyumu, bireyin iş yaşamın değerlendirmesi neticesinde hissettiği tatmin duygusudur. Bireylerin iş doyumunun sağlanması işe olan ilgilerinin ve örgüte olan bağlllıklarının artmasın să̆lar. Tükenmişlik bireyin çeşitli nedenlerden dolayı kendisini bitkin, bıkkın, mutsuz, huzursuz, başarısız, umutsuz ve çaresiz hissettiği ve duygusal tükenme, duyarsızlaşma ve kişisel başarısızlık şeklinde ortaya çıkan psikolojik bir hastalıktır. Bu çalışma, Şanlıurfa'da faaliyet gösteren bankalarda çalışan bireylerin işe yabancılaşma düzeyi, iş doyumu düzeyi ve tükenmişlik düzeyi arasındaki ilişkiyi ortaya koymak amacıyla yapılmıştır. Araştırma amacı doğrultusunda oluşturulan anket 214 banka çalışanına gönüllülük esası ile uygulanmıştır. Katılımcıların işe yabancılaşma, iş doyumu ve tükenmişlik düzeyleri arasındaki ilişkiyi belirlemek için yapılan spearman korelasyon analizi sonucunda işe yabancilaşma ve iş doyumu arasında negatif ve düşük bir ilişki olduğu, işe yabanclaşma ve tükenmişlik düzeyleri arasında pozitif ve orta bir ilişki olduğu ve iş doyumu ve tükenmişlik düzeyi arasında negatif ve düşük bir ilişki olduğu sonucuna ulaşılmıştır.

Anahtar Kelimeler: Işe Yabancılaşma, İş Doyumu, Tükenmişlik, Banka Çalışanları 
ISSN: 2528-9527

E-ISSN : 2528-9535

Yıl Year: 11

Cilt Volume: 17

Sayı Issue:37

Uluslararası Toplum Araştırmaları Dergisi

International Journal of Society Researches

Mayıs May 2021

Makalenin Gelis Tarihi Received Date. 04/11/2020

Makalenin Kabul Tarihi Accepted Date. 25/05/2021

\title{
The Relationship Between Job Satisfaction, Alienation And Fatigue In Bank Employees
}

\begin{abstract}
Alienation is an individual's feeling of boredom, unwillingness and disappointment towards her/his job due to various reasons such as career in the organization she/he works, wage, not being recognized by her/his superiors, inability to understand her/his job with the increase of technology usage, and frequent adjustment problems. Job satisfaction is the feeling of satisfaction felt by an individual as a result of her/his evaluation of work life. Providing job satisfaction of individuals increases their interest in work and their commitment to the organization. Fatigue is a psychological illness in which the individual feels exhausted, bored, unhappy, restless, unsuccessful, hopeless and helpless due to various reasons, and emerges as emotional exhaustion, depersonalization and personal failure.

This study was carried out to reveal the relationship between job alienation, job satisfaction and fatigue of individuals working in banks operating in Şanluurfa. The questionnaire, which was created in line with the purpose of the research, was applied to 214 bank employees on a voluntary basis. As a result of the spearman correlation analysis conducted to determine the relationship between job alienation, job satisfaction and fatigue levels of the participants, it was found that there was a negative and low relationship between job alienation and job satisfaction, a positive and moderate relationship between job alienation an
\end{abstract}

Keywords: Alienation, Job Satisfaction, Fatigue, Bank Employees 


\section{Giriş}

Hızla değişimin yaşandığ 1 dünyada değişen koşullarla hayatta kalma mücadelesi dünyada var olan herkes için korkutucu olsa da vazgeçilmez bir sistematik düzendir. Şüphesiz ki bu değişimden en çok insanlar etkilenmektedir. İnsan olgusunun etkilenmesi demek düzen içinde var olan diğer varlıklarında etkilenmesi anlamına gelmektedir. Bu etkileşimin sonucu maddi ve manevi birçok değişim ve sonucu beraberinde getirmektedir. İşe yabanc1laşma, iş doyumu ve tükenmişlik kavramları da bu değişimlerin etkileri arasındadır. Bireyleri önce psikolojik olarak etkileyip daha sonra maddi ve manevi birçok kayıp yaşamasına neden olan durumlardır.

İşe yabancılaşma, insanın çeşitli nedenlerden dolayı kendi özüne dönmesidir. Kısaca yalnızlığın ifadesidir. İnsanın çalıştığı işten, yakın çevresinden uzaklaşarak yabancılaşmasını ifade eder. Kişi verilen görevi yaparken kendi varlığı ile çatışmasıdır. Kendi varlığı yalnızlığı kabul etmişken çalışmak zorunda olması yaptığı işin anlamsız bulması sonucunu doğurur. İşinde hissettiği mutsuzluk ve uzaklaşma durumu işe yabancılaşmanın özüdür (Mottaz, 1981, s. 515).

İş doyumu, bireyin çalışmakta olduğu iş ile kendi duygu düşünceleri arasındaki orantılı ilişkinin özetidir. Birey işini severek yapıyor olması iş doyumunun sağlandığının göstergesidir. İş doyumu kavramı duygusal nitelikli bir kavramdır bu sebeple de hissiyat önemlidir. Duygu ve hislerin bir bütün olarak değerlendirilmesi, kişinin fiziksel ve ruhsal olarak iyi durumda olması zihinsel açıdan iş doyumunun sağlandığının ifadesidir. Fizikken iyi olmak, genç olmak, iyi bir gelire sahip olmakta iş doyumuna pozitif etki eder (Oshagbemi, 2000, s. 746).

Tükenmişlik ise bir çeşit hastalıklı ruh halidir. Kişinin kendini mutsuz, huzursuz, bitkin, bıkkın, çaresiz hissetmesidir. Tükenmişlik kişisel olarak tüm kaynakların tüketildiği, yaşam enerjinin bittiği ve artık ne yaparsa yapsın bir şeylerin düzelemeyeceği inancının ağır bastığı psikolojidir. Psikolojik belirtilerle beraber uykusuzluk problemleri, baş ağrıları gibi çeşitli ağrılar da bunlara eşlik etmektedir. Bütün bu duygular biranda ortaya çımayıp zamanla artarak devam etmektedir (Farber, 1984, s. 325).

İşe yabancılaşma, iş doyumu ve tükenmişlik kavramları sadece bireyi etkilemekle kalmayıp örgütlere de ciddi zararlar vermektedir. Bireylerin daha verimli ve kaliteli bir hayat yaşaması, örgütlerin de hedeflerine ulaşabilmesi 
adına bu kavramları tanıyıp onlarla mücadele konusunda bilinçlenmesi önem arz etmektedir. Literatürde bu kavramları ayrı ayrı ya da kavramlar arsındaki ilişkiyi ikili yöntemle inceleyen çalışmalar bulunmaktadır. Ancak bu üç kavram arasındaki ilişkiyi inceleyen çalışmanın literatürde yer almaması çalışmayı önemli kılmaktadır.

\section{Kavramsal Çerçeve}

\section{İşe Yabancılaşma}

Yabancılaşma kökeni Farsça bir kelime olan Türkçe karşıllğı ise yaban olan bir sözcükten gelmektedir. Yaban, boş 1ssız yer, yabancı yerden olan gibi manalar taşımaktadır (Eyüboğlu, 1995, s. 714).

Yabancılaşma insanın kendi özünden uzak yaşamayı seçmesidir. Kendi özünden uzak yaşaması demek çevresinden toplumundan ayrı düştüğü bir dönem demektir. Yabancılaşma, insanın kendinden uzaklaşarak yalnızlığa ve çaresizliğe sürüklenmesiyle birlikte kendine ve çevresine olan güvenini kaybetmesine neden olan bir çeşit psikolojik rahatsılıktır. Psikolojik etkileriyle beraber psiko-sosyal etkileri olan çoğunlukla da sosyal ilişkilerde varl-ğını hissettiren bir durumdur (Şimşek, Balay, \& Şimşek, 2012, s. 54).

Yabancılaşma bir vazgeçiştir. Bireyin kendinden, çevresinden ayrı düşmesi uzak durmayı tercih etmesi vazgeçişin simgesidir. Çevresiyle sıcak ilişkiler kurmaktan vazgeçişi kendinden vaz geçmişliğinin sonucudur. Birey toplumsal bir varlık olması sebebiyle kendinden vazgeçmesi toplumdan vazgeçmesine neden olur. Kısacası kendi özünde başlayan yabancılaşmanın çevresine yansımasıdır (Bademci, 2001, s. 29).

İşe yabancılaşma ise, bireyin çalıştığı örgüte çeşitli sebeplerden dolayı bıkkınlık, isteksizlik, hayal kırıklığı hissetmesidir. Örgüt tarafından kariyer, ücret, üstleri tarafından tanınmama gibi beklentileri karşılanamayan çalışanın örgütüne karşı hissettiği doyumsuzluk haline işe yabancılaşma diyebiliriz. Bu duygularla beraber teknolojinin artışıyla çalışan ne iş yaptığının tam olarak farkına varamadığından örgütünden soğumaya başlar. Psikolojik olarak uzaklaşan birey süreç içerisinde kendini geri çekerek örgütten uzaklaşır ve yabancılaşır (Günsal, 2010, s. 76).

İş yaşamındaki hareketlilik, sık sık çalışan görevlerini değişmesiyle birlikte çalışanın uyum sürecinde yaşadığı sıkıntılarla örgütteki görevinden uzaklaşmaya ve kendi kabuğuna çekilmesi sürecini işe yabancılaşma olarak 
tanımlanmaktadır. Değişimler ve teknolojik ilerlemeler bireyin kendini göstermesine fırsat vermeyeceğinden kişi başarılı olma gayretinden vazgeçer ve örgütünden uzaklaşır (Şimşek, Çelik, Akgemci, \& Fettahlıoğlu, 2006, s. 569).Çalışanın örgütünden uzaklaşmaya başlamasına rağmen para kazanma güdüsü sistemde çalışmasının zorunluluğu ile işine devam eder. Çalı̧̧maya sistem tarafından mecbur bırakılan birey isteksizlik ile işe yabancılaşma sürecine dâhil olur (Atiker, 1998, s. 96).

\section{İşe Yabancılaşmanın Nedenleri}

İçinde yaşadığımız çağın insanlar üzerinde etkisi işe yabancılaşmanın nedenleri arasındadır. Teknolojinin gelişmesiyle insanların hızlı değişim karşısında sergileyeceği tutum ve davranışlar işe yabancılaşma üzerinde etkilidir. Aynı şekilde doğanın tahrip edilmesi ve kentleşmenin artması, sanayileşmenin etkileri insanlara yansımaktadır. Kentleşme ile birlikte insanların evleriyle iş yerleri arasında ulaşım problemleri, yaşadığı bölgenin kültürel yapısı çalışma koşulları kişi üzerinde stres faktörünü artırarak işe yabancılaşmasına neden olmaktadır (Güçlü, 2003, s. 74;Aytaç, 2005, s. 325).

Çalışılan kurumun yönetim şekli, iletişim ağı, verilen görevlerin içeriği, çalışılan yerin fiziksel şartları, kazanılan ücret miktarı, terfi ve kariyer imkânları, çalışma süresi, fazla iş yükü verilmesi bireyi doğrudan etkilemektedir. Yeterli imkânları sunamayan kurumlar, çalışanlarını işe yabancılaşmaya iten faktörlerin başında yer alır (Çakır, 2006, s. 112 ;Dinçer, 1998, s. 5).

İşe yabancılaşma olgusuna belirtiğimiz bu nedenlerle beraber kişinin kişisel özellikleri etki etmektedir. Kişinin çalıştığı kurumdan ne beklediği, hayata karşı bakış açısı, işini sevmesi ve benimsemesi, diğer çalışanlara karşı tutum davranışları, içinde bulunduğu ruh hali işe yabancılaşmaya doğrudan etkilidir (Başaran, 2008, s. 222).

\section{İşe Yabancılaşmanın Sonuçları}

İşe yabancılaşma en başta bireyi etkileyen ona bağlı olarak da çalıştı̆̆ $\mathrm{ku}$ rumu etkileyen bir döngüdür. İnsanın yaşamdan, ilişkilerinden giderek uzaklaşması örgütlerde makinelerin etkin konuma gelmesiyle de insanın etkinliğini kaybetmesine neden olur. Etkinliği kaybolan birey işe yaramadığını düşünerek mutsuz olur ve verimsiz çalışır, düşük motivasyon sergiler, işten soğur ve iş doyumunu kaybeder (Tutar, 2004, s. 183). 
Yabancılaşan birey yaratıc1lı özelliklerini kaybeder. İnsanlarla iletişim kurmak ona yük olarak gelir. Sorumluluk almak istemediği için önemli kararlar alınırken geri planda durur bu da onu pasif bir kişiliğe dönüştürür. Hayattan zevk almaz ve her şeyden sürekli olarak şikâyet eder. İş yaşamında faydalı olamayacağında bir süre sonra işten ayrılmaya niyetlenir. İşten ayrılmaya niyetlenmesine rağmen o işte çalışmak zorundaysa o işten ayrılamıyorsa çareyi kendini dış dünyaya kapatmakta bulur (Ehtiyar \& Yanardă̆, 2008, s. 59).

Örgütsel yabancılaşma olgusunun iş tatmini üzerine etkisinin incelecelendiği çalışmada işe yabancllaşmanın iş doyumunu negatif yönde etkilediği gözlemlenmiştir. İş doyumu arttıkça işe yabancılaşmanın azaldığı sonucu elde edilmiştir (Koyuncu ve Yalçın, 2014, s. 92)

\section{İş Doyumu}

İnsanlar günlük hayatlarını devam ettirebilmek ve ihtiyaçlarını karşılayabilmek belli bir statüye ulaşmak adına bir işte çalışmaktadırlar. Bireyin çalıştığ 1 iş bütün hayatını etkilemektedir. Bireyin iş hayatında yaşadığı olumlu ya da olumsuz duygular özel hayatını etkilediği gibi özel hayatında yaşadıkları da iş hayatına etki etmektedir. Bireyin işyerlerinde karşılaştıkları durumlar karşısında sergilediği tutum ve davranışlar iş doyumunu simgeler. İş doyumu duygusal tepkilerin bütünü olduğundan soyut bir kavramdır. Bireyin işine karşı ne hissettiğini ifade eder. Olumlu duygular iş doyumu olarak tanımlanır (Erdoğan, 1996, s. 231).

İş doyumu bireyin yaptığı işin özellikleri ile kendi isteklerinin benzeşmesidir. Bireyin yaptığ işten duyduğu hazzı ifade eder. İşini yaparken mutluysa iş doyumu, mutsuz ise iş doyumsuzluğu yaşanmaktadır. Kısaca bireyin işine karşı verdiği duygusal tepkilerin karşılığıdır. İşini yaparken mutlu olan birey yüksek performansla çalışır, işine olan bağlılığının artışıyla yaratıcılı̆̆ı artar ve örgütüne daha fazla faydalı olur. Yaptı̆̆ işi anlamlı bulan birey kendini de değerli hisseder bu da iş doyumu artışını sağlar (Keser, 2006, s. 105).

\section{İş Doyumunu Etkileyen Faktörler}

İş doyumunu etkileyen faktörlerden birisi örgütsel faktörler diğeri ise bireysel faktörlerdir. Bireysel faktörlerin başında kişinin doğuşundan kaynaklanan kişilik özellikleri gelmektedir. Öz güveni yüksek, her durumda pozitif 
düşünebilen ve yaratıcılık özelliği yüksek bireyler ortak değerler sahip olduğu bireylerle bir arada çalışması ise iş doyumunun artışını sağlar. Kişilik özellikleri ile birlikte ortak değerlere ve inanca sahip olmak iş doyumuna olumlu etki eder (Erkmen \& Şencan, 1994, s. 144).

Kişilerin zamanla kazandığ tecrübeler bir diğer bireysel faktörü oluşturmaktadır. İşinde tecrübe kazanmış bireyler karşılaştıkları sorunların çözümünde daha başarılı olduklarından iş doyumları yüksektir. Tecrübeyle bağlantılı iş doyumunu etkileyen bir diğer faktör ise bireyin yaşıdır. Bireyin yaşının artışıyla da iş doyumu doğru orantılı olarak artmaktadır (Sevimli \& İşcan, 2005, s. 57).

Cinsiyet açısından değerlendirildiğinde ise erkeklerin mi bayanların $\mathrm{m} 1$ daha fazla iş doyum elde ettikleri konusunda tutarsız sonuçlar bulunmaktadır (Korman, Akhun, ve Alkan, 1978, s. 179).

İş doyumunu etkileyen örgütsel faktörler ise çalışılan işin kendisi başta olmak üzere çalışma koşulları, örgütün yönetim biçimi, örgütte çalışan diğer personellerin tutum ve davranışları, ücret politikaları, kıdem ve terfi olanakları iş doyumunu doğrudan etkileyen faktörlerdir. İşin yapısının bireyin kişilik özellikleri ile uyumlu olması, işin zorluk derecesiyle başa çıkabilme potansiyelinin bireyde olması, adaletli bir şekilde terfi sisteminin işlemesi ve buna paralel adaletli ücret politikalarının uygulanması çalışanın iş doyumunu artırır. Alınan ücret ne kadar yüksekse iş doyumu doğru orantılı olarak artış gösterir (Kolasa, 1969, s. 455).

\section{İş Doyumunun Önemi ve Sonuçlan}

Bireyin çalıştı̆̆ iş tüm hayatına etki ettiğinden son derece önemlidir. Bireyin psikolojik ve fiziksel olarak etkilemektedir. Bu etki sonuçları hem maddi hem de manevi olarak kendini göstermektedir. İş doyumuna ulaşan bireyin iş ve özel hayatı olumlu olarak etkilenirken, doyumsuzluk yaşayan bireyin özel hayatında da sorunlar yaşadığı ve psikolojik sorunlar yaşadıkları görülür (Başaran, 2008, s. 222).

İş doyumunun örgüte kattı̆̆ faydaların yanı sıra iş doyumsuzluğunun olumsuz etkilerinin maliyeti de örgüt için oldukça fazladır. Başarılı bir şekilde yönetilen, insan ilişkilerine önem veren örgütlerin iş doyumu yakaladıkları ve huzurlu iş ortamını sağladıklarından iş doyumu gerçekleşir. İyi yönetilmeyen örgütlerde ise görülen iş doyumsuzluğu sonuçlarında örgütte ani 
grevler yaşanması, iş yavaşlatma, verimsiz çalışma, disiplinsiz davranışlar ve örgüt içi çatışmalara sebep olmaktadır. İşverenlerin tavırları çalışanlar üzerinde doğrudan etki etmektedir. Personelin işten ayrılmasının ve yeni personelin eğitilmesi sürecinin yeni maliyetleri getirileceği gibi diğer personellerin motivasyonunun düşüşüne sebep olduğu da düşünülerek yöneticilerin sorumluluğu artmaktadır (Çalışkan, 2005, s. 10).

Sağlık çalışanlarının tükenmişlik, iş doyumu ve yaşam doyumları incelenmesi amacıyla yapılan çalışmada iş ve yaşam doyumu düşük olan çalışanların tükenmişlik oranlarının yüksek olduğu gözlemlenmiştir (Tekir, Çevik, Arık, ve Çetin, 2016, s. 61).

Devlet üniversitesi idari personellerin katılımıyla yapılan çalışmada iş doyumu ve işe yabancılaşma arasında sıkı bir bağın olduğu ortaya konulmuştur. İş görenlerin iş doyumu azaldıkça işe yabanclaşmanın arttığı gözlemlenmiştir (Turan ve Parsak, 2011, s. 16).

\section{Tükenmişlik}

Tükenmişlik bireyin çeşitli nedenlerden dolayı bitkin, bıkkın, mutsuz, huzursuz, başarısız, umutsuz ve çaresiz hissettiği psikolojik bir hastalıktır. Tükenmişlik insan ilişkilerinin aktif olduğu sektörlerde ortaya çıkan bireylerarası duygusal tükenme sendromudur. Duygusal tükenmeyle ortaya çıkan psikolojik bir rahatsızlıktır (Maslach ve Jackson, 1981, s. 99).

Tükenmişlik, gitgide artan bir süreç olup bir süre sonra içinden çıkılamaz bir durum haline gelmektedir. Zaman içinde bu duruma alş̧an birey bu şekilde yaşamayı kabul eder ve toparlanmak için hiçbir çaba sarf etmek istemez. Yaratııılığın kaybolması, başarısız olmayı kabul etmek, iş arkadaşlarından ve çevresinden uzaklaşmak ve en önemlisi bu duygularla yaşamayı kabullenmek tükenmişliği tanımlar (Çam, 1992, s. 155).

Tükenmişliğin ortaya çıkmasında bireysel ve örgütsel nedenler bulunmaktadır. Bireyin yaşı, medeni durumu, eğitim seviyesi, aile yaşantısı, arkadaşlık iliş̧kileri, işine bakış açısı, hayattan beklentisi, kendine olan saygısı, özgüveni ve diğer kişilik özelliklerini bireysel nedenler arasında sıralayabiliriz (Sürgevil, 2006, s. 50).

Örgütsel nedenler olarak ise bireyin çalıştı̆̆ işin cinsi, çalışma şekli, çalışma zamanı, aldığı ücret, bulunduğu pozisyon, yöneticilerin çalışanlara 
karşı tutumu, diğer çalışanlarla birey arasındaki iletişim tükenmişlik üzerinde etkilidir (Izgar, 2003, s. 168).

\section{Tükenmişliğin Belirtileri}

Tükenmişliğin fiziksel, davranışsal, psikolojik ve ruhsal birçok belirtisi bulunmaktadır (Kaçmaz, 2005, s. 30)

Fiziksel Belirtileri: Fizikken kişinin kendini hastalıklı hissetmesi halidir. Sürekli olarak uyku ihtiyacı hissetmesi, ciddi baş ağrıları, her an yorgunluk hissetmesi, kramplar şeklinde oluşan kas ağrıları, hastalıklarla baş edebilecek gücü kendinde bulamaması gibi genel belirtiler tükenmişliğin fiziksel belirtileri arasındadır.

Davranışsal Belirtileri: Aniden öfkelenmesi ve ağlama krizlerinin ortaya çıkması, alıngan davranıp içine kapanmaya başlaması, hiçbir eleştiriyi kabul etmemesi, işinden soğuması ve işe gitmemek için bahaneler yaratması, başarısız olurum korkusu ile adapte olamaması, her şeyden şüphe etmesi davranışsal belirtilerdir

Psikolojik ve Ruhsal Belirtiler: iş yerinde başlayan sorunlar özel hayata yansıyıp aile içi sorunlarla kendini göstermektedir. Yaşanılanların etkisiyle uykusuzluk problemleri, depresyon ve birçok psikolojik hastalı̆̆ın belirtileri ortaya çıkmaktadır.

\section{Tükenmişlikle Baş Edebilmenin Yollan}

Tükenmiş bireyi sessiz sedasız ele geçiren bir düşman veya hastalık gibi tanımlamak onunla mücadele etmekte kolaylık sağlayacaktır. Hastalık ortaya çıktıktan sonra yapılan mücadele çok fazla işe yaramayacağını düşünecek olursa tükenmişliğin ortaya çıkmadan gerekli önlemleri almamız daha faydalı olacaktır. Bu önlemleri almak en başta bireyin kendi görevi olmalıdır çünkü bu durumdan en fazla etkilen bireydir.

Birey kendi sağllğı her şeyden önemli olduğunu düşünerek moral ve enerjisini sürekli yüksek tutmaya çalışmalıdır. Fiziki egzersizlerle beraber müzik, resim, dans gibi çeşitli sosyal faaliyetleri hobi edinmesinde fayda görülmektedir (Torun, 1997, s. 49)

Birey çalışma zamanlarında mola sürelerinde mola vermeli, hafta sonu tatillerinde tatil yaparak geçirmeli ve yıllık izinlerini mutlaka kullanmalıdır. Bireyin doğru zamanlarda verdiği çalışma molalar yaşam kalitesini artırarak 
tükenmişliğe engel olmaktadır. Örgütte daha başarılı ve verimli çalışma ortamlarının yaratılması adına yöneticiler çalışanların uygun olduğu işlerde çalışmaları konusunda desteklemeli, grup toplantıları düzenleyerek iletişim ağının güçlenmesine destek olmall, iş rotasyonlarını düzenleyerek personelin gelişimine aracılık etmesi stres faktörünün artışını engellediği gibi tükenmişliğin yaşanmasına da engel olacaktır (Levinson, 1996, s. 161).

Tükenmişlik ile ilgili yapılan çalışmalarda tükenmişlik sendromunun işe yabancılaşmanın bir sonucu olduğu gözlemlenmiştir. Bu anlamda da iki kavramın birbirini etkilediğini görmekteyiz (Özler \& Dirican, 2015, s. 296)

Beden eğitimi öğretmenlerinin mesleki tükenmişlik ve iş doyumu açısından incelendiği çalışmada mesleki tükenmişlik artıkça iş doyumunun azaldığı belirlenmiştir (Gençay, 2007, s. 778).

\section{Araştırma Metedolojisi}

\section{Araştırmanın Amacı}

Bu çalışmada, Şanlıurfa'da faaliyet gösteren bankalarda çalışan bireylerin işe yabancılaşma düzeyi, iş doyumu düzeyi ve tükenmişlik düzeyi arasındaki ilişkiyi ortaya koymak amaçlanmıştır.

\section{Örnekleme Süreci}

Verilerin toplanmasında zaman, maliyet ve verilerin eskimesi gibi kısıtlar nedeni ile örnekleme yoluna gidilmiştir. Araştırmanın ana kütlesi Şanlıurfa'da bankalarda çalışan bireyleri kapsamaktadır. Verilerin toplanmasında online anket yöntemi ve kolayda örnekleme yöntemi kullanılmıştır. Anketler 15.06.2020 ile 15.08.2020 tarihleri arasında iki ay süre ile Şanlıurfa'daki bankalarda çalışan 214 bireye gönüllülï̈k esasına göre uygulanmıştır.

\section{Veri Toplama Yöntemi ve Aracı}

Araştırma için gerekli olan birincil veriler, anket metodu uygulanarak toplanmıştır. Araştırma için hazırlanan anket dört bölümden oluşmaktadır. Birinci bölümde, Çevik (2019) tarafından “Örgütsel Sağlığın İşe Yabancılaşma Üzerine Etkisi Kahramanmaraş Çelik Fabrikalarında Bir Uygulama” isimli çalı̧̧mada kullanılan 24 maddelik işe yabancılaşma ölçeği yer almaktadır. İkinci 
bölümde, Orhaner Gündüz (2016) tarafından “Banka Çalışanlarında İş Doyumu ve İş Doyumunun Örgütsel Bağlılığa Etkisi" isimli çalışmada kullanılan 14 maddelik iş doyumu ölçeği yer almaktadır. Üçüncü bölümde, Maslach ve Jackson (1981) tarafından geliştirilen 22 maddelik Maslach Tükenmişlik Ölçeği yer almaktadır. Dördüncü bölümde ise, cinsiyet, medeni durum, yaş, ortalama gelir düzeyi, eğitim düzeyini ve toplam çalışma süresini ölçen 6 demografik faktör sorusu yer almaktadır. Ölçekler 5'li likert ile ölçülmüştür.

\section{Araştırmanın Modeli ve Hipotezleri}

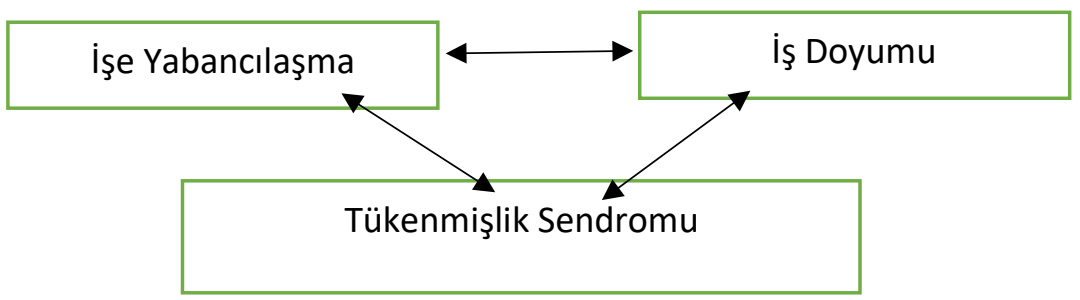

Şekil 1. Araştırmanın Modeli

Araştırmanın modeli doğrultusunda geliştirilen hipotezler şu şekildedir:

- H1: Şanlıurfa'daki bankalarda çalışan bireylerin işe yabanclaşma düzeyi, iş doyum düzeyi ve tükenmişlik düzeyleri arasında anlamlı bir ilişki vardır.

- H1a: Şanhurfa'daki bankalarda çalışan bireylerin işe yabancılaşma düzeyi ve iş doyum düzeyi arasında anlaml bir ilişki vardır.

- H1b: Şanlıurfa'daki bankalarda çalışan bireylerin işe yabancilaşma düzeyi ve tükenmişlik düzeyleri arasında anlamlı bir ilişki vardır.

- H1c: Şanlıurfa'daki bankalarda çalışan bireylerin iş doyum düzeyi ve tükenmişlik düzeyleri ve tükenmişlik düzeyleri arasında anlamlı bir ilişki vardır.

\section{Verilerin Analizi}

Araştırmada elde edilen veriler SPSS (Statistical Package for Social Sciences) for Windows 25.0 programı kullanılarak analiz edilmiştir. Verileri değerlendirilirken tanımlayıcı istatistiksel metotları (sayı, yüzde, ortalama) kullanımıştır. Verilerde normal dağılıma uygunluk Q-Q Plot çizimi ile incelenebilir. Ayrıca, kullanılan verilerin normal dağılım göstermesi çarpıklık ve basıklık değerlerinin \pm 3 arasında olmasına bağlıdır. Normal dağılım uygunluk nor- 
mallik testleri ve basıklık çarpıklık değerleri ile kontrol edilmiştir. Veriler değerlendirildiğinde normal dağılım varsayımının sağlanmadığı tespit edilmiştir.

Verilerin analizinde normal dağılım varsayımı sağlanmadığı için sürekli verilerde ilişkinin incelenmesi için Spearman korelasyon analizi yapılmıştır.

Yapılan testlerin ve sonuçların güvenilir olabilmesi için ölçeklerin güvenilir olması gerekmektedir. Bu bağlamda ölçeklere ve alt boyutlara ilişkin güvenirlikler Cronbach Alpha ile incelenmiştir. Ayrıca ölçeklere ilişkin açıklayıcı faktör analizi yapılarak yapı geçerliliği test edilmiştir.

\section{Etik Kurul Onayı}

“Banka Çalışanlarında İşe Yabancılaşma, İş Doyumu ve Tükenmişlik Arasındaki İlişki" konulu çalışmam ile Harran Üniversitesi Sosyal ve Beşeri Bilimler Etik Kurulu'na başvurulmuş olup, 09.06.2020 tarih ve 2020/44 sayılı karar ile etik açıdan çalışmanın yapılmasının uygun olduğuna oy birliği ile karar verilmiştir.

\section{Güvenilirlik Analizi}

Tablo 1. Güvenirlilik Analizi Sonuçlan

\begin{tabular}{lll}
\hline Faktör Adı & Cronbach's Alpha & Madde Sayısı \\
\hline İşe Yabancilaşma &, 858 & 24 \\
\hline İş Doyumu &, 874 & 14 \\
\hline Tükenmişlik Sendromu &, 901 & 22 \\
\hline
\end{tabular}

Eğer; Cronbach Alpha değeri $.00<\alpha<.40$ ölçek güvenilir değil, $.40<\alpha<.60$ ölçeğin güvenilirliği düşük, . $60<\alpha<.80$ ölçek oldukça güvenilir ve $.80<\alpha<1.00$ ölçek yüksek derecede güvenilirdir yorumu yapılmaktadır (Arslan ve Nur, 2018, s.342). Bu durumda kullanılan ölçeklerin yüksek derecede güvenilir olduğu tespit edilmiştir.

\section{Açıklayıcı Faktör Analizi}

Tablo 2. İşe Yabancılaşma Düzeyine Yönelik Değişkenlere İlişkin KMO Örneklem Yeterliliği Ölçeği ve Bartlett Kïresellik Testi Değeri

\begin{tabular}{lll}
\hline KMO &, 816 & \\
\hline Bartlett Küresellik Testi & Yaklaşı Ki-Kare & 5134,693 \\
\cline { 2 - 3 } & Df. & 276 \\
\cline { 2 - 3 } & Sig. &, 000 \\
\hline
\end{tabular}


Tablo 2' de, KMO değeri $(0,816)$ ve Bartlett testi Significance $=0,000$ olduğundan ve $\mathrm{p}<0.05$ koşulunu sağlamasından dolayı verilerin faktör analizi için uygun olduğuna karar verilmiştir. Analiz sonucunda, işe yabanclaşma ölçeğindeki ifadelerin beş ayrı boyutta toplandığı görülmüş̧ür.

Tablo 3. İşe Yabancılaşma Düzeyini Ölçmeye Yönelik Değişkenlere İlişkin Faktör Analizi Sonuçlan

\begin{tabular}{|c|c|c|c|}
\hline $\begin{array}{l}\text { Ölçek } \\
\text { Alt Boyutları }\end{array}$ & Maddeler & $\begin{array}{l}\text { Yük } \\
\text { De- } \\
\text { gerleri }\end{array}$ & $\begin{array}{l}\text { Açıllanan } \\
\text { Varyans (\%) }\end{array}$ \\
\hline \multirow{4}{*}{ Güşsüzlük } & $\begin{array}{l}\text { Yapacağım işlerin içeriği benim dışımdaki kişiler tarafın- } \\
\text { dan belirleniyor. }\end{array}$ & ,856 & \multirow{4}{*}{40,138} \\
\hline & $\begin{array}{l}\text { Yaptığım işlerin kıymetsiz bir parçası haline geldiğimi his- } \\
\text { sediyorum. }\end{array}$ & 899 & \\
\hline & $\begin{array}{l}\text { İşlerimle ilgili ortaya çıkan sorunlarla mücadele etme gü- } \\
\text { cümü yitirdiğimi hissediyorum. }\end{array}$ & ,767 & \\
\hline & $\begin{array}{l}\text { Yaptığım işlerde kontrolün tam olarak bende olmadığını } \\
\text { düşünüyorum }\end{array}$ & ,684 & \\
\hline \multirow{5}{*}{ Anlamsizlık } & $\begin{array}{l}\text { İşletmede gerçekleşen olayların birçoğuna anlam veremi- } \\
\text { yorum. }\end{array}$ & ,848 & \multirow{5}{*}{18,496} \\
\hline & $\begin{array}{l}\text { Uygulanan kuralların gerçekten anlamlı olmadığını düşü- } \\
\text { nüyorum. }\end{array}$ & ,810 & \\
\hline & $\begin{array}{l}\text { İş hayatında dürüst olup olmamak başarılı olmak açısın- } \\
\text { dan herhangi bir anlam ifade etmiyor }\end{array}$ & ,858 & \\
\hline & $\begin{array}{l}\text { İşletmede yapılanların doğru veya yanlış olduğuna tam } \\
\text { olarak karar veremiyorum. }\end{array}$ & ,735 & \\
\hline & İşletmede ortaya konulan doğruları anlamlı bulmuyorum. & ,595 & \\
\hline \multirow{5}{*}{ Kuralsılılk } & $\begin{array}{l}\text { Önemli amaçlara ulaşabilmek için gerekirse kurallar gö- } \\
\text { zardı edilebilir }\end{array}$ & ,867 & \multirow{5}{*}{9,171} \\
\hline & Gerektiğinde kurallara uymayabileceğime inanıyorum & ,561 & \\
\hline & $\begin{array}{l}\text { İsler görüldü̈kten sonra kurallara uyulup uyulmadığı çok } \\
\text { önemli değildir }\end{array}$ & ,718 & \\
\hline & $\begin{array}{l}\text { İşletmede bulunan birçok kuralın beni kısıtladığını düşü- } \\
\text { nüyorum. }\end{array}$ & ,601 & \\
\hline & $\begin{array}{l}\text { Başarılı olabilmek için bazen kuralların dışına çıkılması } \\
\text { gerektiğini düşünüyorum. }\end{array}$ & ,674 & \\
\hline \multirow{5}{*}{$\begin{array}{l}\text { Toplumsal Ya- } \\
\text { bancılaşma }\end{array}$} & Çevremdeki insanlara kendimi yabancı gibi hissediyorum & 713 & \multirow{5}{*}{4,870} \\
\hline & $\begin{array}{l}\text { Kendimi çevremdeki insan topluluğunun bir parçası ola- } \\
\text { rak göremiyorum. }\end{array}$ & ,858 & \\
\hline & $\begin{array}{l}\text { Çevremdeki insanların yanında kendimi yalnız hissediyo- } \\
\text { rum. }\end{array}$ & ,694 & \\
\hline & $\begin{array}{l}\text { Çevremdeki insanların çok önem verdiği şeylerin benim } \\
\text { için o kadar da önemli olmadığını düşünüyorum }\end{array}$ &, 582 & \\
\hline & $\begin{array}{l}\text { Yaptığım işin, bana hayata kendimi kanıtlama fırsatı ver- } \\
\text { mediğini düşünüyorum. }\end{array}$ & ,788 & \\
\hline
\end{tabular}




\begin{tabular}{lll}
\hline $\begin{array}{l}\text { Kendine } \\
\text { Yabancılaşma }\end{array}$ & Yaptığım işin beni ifade etmediğini düşünüyorum. & 3,906 \\
\cline { 2 - 3 } & $\begin{array}{l}\text { Yaptığım iş ile yaşam tarzımın uyuşmadığını düşünüyo- } \\
\text { rum }\end{array}$ & ,703 \\
\cline { 2 - 3 } $\begin{array}{l}\text { Daha iyi yaşamak için çalışan değil de sadece çalışmak için } \\
\text { yaşayan birine dönüştüğümü düşünüyorum }\end{array}$ & 725 \\
\cline { 2 - 3 } & $\begin{array}{l}\text { Hayattan beklentilerimin sürekli değiştiğini fark ediyo- } \\
\text { rum }\end{array}$ & ,734 \\
\hline & $\begin{array}{l}\text { Gelecekten beklentilerim ile içinde bulunduğum koşulla- } \\
\text { rın uyuşmadığını düşünüyorum }\end{array}$ & ,728 \\
\hline
\end{tabular}

Toplam Açıklanan Varyans (\%): 76,602

Tablo 4. İş Doyumu Düzeyine Yönelik Değişkenlere İlişkin KMO Örneklem Yeterliliği Ölçeği ve Bartlett Küresellik Testi Değeri

\begin{tabular}{lll}
\hline KMO &, 841 & \\
\hline Bartlett Küresellik Testi & Yaklaşık Ki-Kare & 2250,108 \\
\cline { 2 - 3 } & Df. & 91 \\
\cline { 2 - 3 } & Sig. &, 000 \\
\hline
\end{tabular}

Tablo 4'te, KMO değeri $(0,816)$ ve Bartlett testi Significance $=0,000$ olduğundan ve $\mathrm{p}<0.05$ koşulunu sağlamasından dolayı verilerin faktör analizi için uygun olduğuna karar verilmiştir. Analiz sonucunda, işe doyumu ölçeğindeki ifadelerin tek boyutta toplandığı görülmüştür.

Tablo 5. İş Doyumu Düzeyini Ölçmeye Yönelik Değişkenlere İlişkin Faktör Analizi Sonuçlarn

\begin{tabular}{|c|c|c|c|}
\hline $\begin{array}{l}\text { Ölçek } \\
\text { Alt Boyutları }\end{array}$ & Maddeler & $\begin{array}{l}\text { Yük Değer- } \\
\text { leri }\end{array}$ & $\begin{array}{l}\text { Açıklanan } \\
\text { Varyans (\%) }\end{array}$ \\
\hline \multirow{10}{*}{ Güçsüzlük } & Şu an çalıştı̆̆ım iş beni tatmin ediyor & ,657 & \multirow{10}{*}{59,022} \\
\hline & Aldığım maaş beni tatmin ediyor & 645 & \\
\hline & $\begin{array}{l}\text { İşimi yaparken edindiğim kişisel gelişim beni tatmin edi- } \\
\text { yor }\end{array}$ & 700 & \\
\hline & $\begin{array}{l}\text { İşyerinde görüştüğüm ve çalıştığım insanlardan mem- } \\
\text { nunum }\end{array}$ & 777 & \\
\hline & $\begin{array}{l}\text { İşyerinde gördüğüm saygı ve adil davranışlar beni } \\
\text { memnun ediyor }\end{array}$ & 672 & \\
\hline & $\begin{array}{l}\text { İşimi yaparken zaman harcamaya değer başarılar elde } \\
\text { edeceğimi düşünüyorum }\end{array}$ & ,634 & \\
\hline & İşyerinde farklı insanlar tanıma şansı elde ediyorum & 646 & \\
\hline & $\begin{array}{l}\text { Üstlerimden gördüğüm destek ve yönlendirmelerden } \\
\text { memnunum }\end{array}$ & 711 & \\
\hline & $\begin{array}{l}\text { İşime gösterdiğim katkı karşılığında aldığım ücretten } \\
\text { memnunum }\end{array}$ & 737 & \\
\hline & $\begin{array}{l}\text { İşimde bağımsız olarak düşünebilir ve hareket edebili- } \\
\text { rim }\end{array}$ & 684 & \\
\hline
\end{tabular}




\begin{tabular}{ll}
$\begin{array}{l}\text { Çalıştı̆̆ım kurumun geleceğim açısından güvenli bir yer } \\
\text { olduğunu düşünüyorum }\end{array}$ & ,697 \\
\hline $\begin{array}{l}\text { İşimde başka insanlara yardım etme şansı beni tatmin } \\
\text { ediyor }\end{array}$ &, 824 \\
\hline İşimdeki zorluk derecesi beni tatmin ediyor &, 702 \\
\hline $\begin{array}{l}\text { İşimde bana gösterilen amirlik seviyesinden memnu- } \\
\text { num }\end{array}$ &, 677
\end{tabular}

Tablo 6. Tükenmişlik Sendromu Düzeyine Yönelik Değişkenlere İlişkin KMO Örneklem Yeterliliği Ölçeği ve Bartlett Küresellik Testi Değeri

\begin{tabular}{lll}
\hline KMO &, 801 & \\
\hline Bartlett Küresellik Testi & Yaklaşık Ki-Kare & 4739,832 \\
\cline { 2 - 3 } & Df. & 231 \\
\cline { 2 - 3 } & Sig. &, 000 \\
\hline
\end{tabular}

Tablo 6'da, KMO değeri $(0,801)$ ve Bartlett testi Significance $=0,000$ olduğundan ve $\mathrm{p}<0.05$ koşulunu sağlamasından dolayı verilerin faktör analizi için uygun olduğuna karar verilmiştir. Analiz sonucunda, tükenmişlik sendromu ölçeğindeki ifadelerin üç ayrı boyutta toplandığı görülmüştür.

Tablo 7. Tükenmişlik Sendromu Düzeyini Ölçmeye Yönelik Değişkenlere İlişkin Faktör Analizi Sonuçları

\begin{tabular}{|c|c|c|c|c|}
\hline $\begin{array}{l}\text { Ölçek } \\
\text { Alt Boyutları }\end{array}$ & Maddeler & $\begin{array}{l}\text { Yük Değer- } \\
\text { leri }\end{array}$ & $\begin{array}{l}\text { Açlklanan } \\
\text { yans }(\%)\end{array}$ & Var- \\
\hline \multirow{9}{*}{$\begin{array}{l}\text { Duygusal Tü- } \\
\text { kenme }\end{array}$} & İşimden soğuduğumu hissediyorum & 707 & \multirow{9}{*}{36,705} & \\
\hline & İş dönüşü kendimi ruhen tükenmiş hissediyorum & 803 & & \\
\hline & $\begin{array}{l}\text { Sabah kalktığımda bir gün daha bu işi kaldırama- } \\
\text { yacağımı hissediyorum }\end{array}$ & 808 & & \\
\hline & $\begin{array}{l}\text { Bütün gün insanlarla uğraşmak benim için gerçek- } \\
\text { ten çok yıpratıcı }\end{array}$ & 752 & & \\
\hline & Yaptığım işten yıldığımı hissediyorum & 673 & & \\
\hline & İşimin beni kısıtladığını hissediyorum &, 590 & & \\
\hline & İşimde çok fazla çalıştığımı hissediyorum &, 594 & & \\
\hline & $\begin{array}{l}\text { Doğrudan insanlarla çalışmak bende çok fazla } \\
\text { stres yaratıyor }\end{array}$ & 770 & & \\
\hline & Yolun sonuna geldiğimi hissediyorum & 648 & & \\
\hline \multirow{5}{*}{ Kişisel Başarı } & $\begin{array}{l}\text { İşim gereği hizmet verdiğim insanların ne hissetti- } \\
\text { ğini hemen anlarım }\end{array}$ & ,761 & \multirow{5}{*}{25,291} & \\
\hline & $\begin{array}{l}\text { İşim gereği hizmet verdiğim insanların sorunla- } \\
\text { rına ne uygun çözüm yollarını bulurum }\end{array}$ & 668 & & \\
\hline & $\begin{array}{l}\text { Yaptığım iş sayesinde insanların yaşamına katkıda } \\
\text { bulunduğuma inanıorum }\end{array}$ & 709 & & \\
\hline & Çok şeyler yapabilecek güçteyim & 751 & & \\
\hline & $\begin{array}{l}\text { İşim gereği hizmet verdiğim insanlarla aramda ra- } \\
\text { hat bir ortam yaratıyorum }\end{array}$ & ,586 & & \\
\hline
\end{tabular}




\begin{tabular}{|c|c|c|c|}
\hline & $\begin{array}{l}\text { İnsanlarla yakın çalışmadan sonra kendimi can- } \\
\text { lanmış hissederim }\end{array}$ & 618 & \\
\hline & Bu işte kayda değer birçok başarı elde ettim & 646 & \\
\hline & $\begin{array}{l}\text { İşimdeki duygusal sorunlara serinkanlılıkla yakla- } \\
\text { şırım }\end{array}$ & ,712 & \\
\hline \multirow{5}{*}{ Duyarsızlaşma } & $\begin{array}{l}\text { İşim gereği hizmet verdiğim bazı kimselere sanki } \\
\text { insan değillermiş gibi davrandığımı hissediyorum }\end{array}$ & 683 & \multirow{5}{*}{7,758} \\
\hline & $\begin{array}{l}\text { Bu işte çalışmaya başladığımdan beri insanlara } \\
\text { karşı sertleştim }\end{array}$ & 620 & \\
\hline & $\begin{array}{l}\text { Bu işin beni giderek katılaştırmasından korkuyo- } \\
\text { rum }\end{array}$ & 645 & \\
\hline & $\begin{array}{l}\text { İşim gereği hizmet verdiğim insanlara ne olduğu } \\
\text { ne olduğu umurumda değil }\end{array}$ & ,555 & \\
\hline & $\begin{array}{l}\text { İşim gereği hizmet verdiğim insanların bazı prob- } \\
\text { lemlerini ben yaratmışım gibi davrandıklarını his- } \\
\text { sediyorum }\end{array}$ & 681 & \\
\hline
\end{tabular}

Toplam Açıklanan Varyans (\%): 69,755

\section{Demografik Bulgular}

Tablo 8. Katılımcılarnn Demografik Özellikleri

\begin{tabular}{|c|c|c|c|}
\hline & & n & $\%$ \\
\hline \multirow[t]{2}{*}{ Cinsiyet } & Kadın & 113 & 52,8 \\
\hline & Erkek & 101 & 47,2 \\
\hline \multirow[t]{2}{*}{ Medeni Durum } & Evli & 163 & 76,2 \\
\hline & Bekar & 51 & 23,8 \\
\hline \multirow[t]{4}{*}{$\overline{\text { Yaş }}$} & $18-28$ & 10 & 4,7 \\
\hline & $29-38$ & 148 & 69,2 \\
\hline & $39-48$ & 53 & 24,8 \\
\hline & $49-58$ & 3 & 1,4 \\
\hline \multirow[t]{3}{*}{ Eğitim Durumu } & Ön lisans & 13 & 6,1 \\
\hline & Lisans & 177 & 82,7 \\
\hline & Lisansüstü & 24 & 11,2 \\
\hline \multirow[t]{5}{*}{ Aylık Gelir Durumu } & 3000 TL ve alt1 & 36 & 16,8 \\
\hline & $3001 \mathrm{TL}-4000 \mathrm{TL}$ & 51 & 23,8 \\
\hline & $4001 \mathrm{TL}-5000 \mathrm{TL}$ & 48 & 22,4 \\
\hline & $5001 \mathrm{TL}-6000 \mathrm{TL}$ & 21 & 9,8 \\
\hline & 6001 TL ve üzeri & 58 & 27,1 \\
\hline \multirow[t]{7}{*}{ İş Tecrübesi } & $1-3$ & 30 & 14,0 \\
\hline & $4-6$ & 91 & 42,5 \\
\hline & $7-9$ & 44 & 20,6 \\
\hline & $10-12$ & 35 & 16,4 \\
\hline & $13-15$ & 4 & 1,9 \\
\hline & $16-18$ & 7 & 3,3 \\
\hline & 19 ve üzeri & 3 & 1,4 \\
\hline
\end{tabular}

Araştırmaya katılan katılımcıların demografik özelliklerine ilişkin bilgiler Tablo 8' de verilmiştir. Sonuçlar incelendiğinde araştırmaya konu olan banka 
çalışanlarının \%52,8'i kadın \%47,2'si erkek; \%76,2'si evli ve \%23,8'i bekar bireylerden oluşmaktadır. Katılımcıların \%69,2'sinin 29-38 yaş aralığında olduğu; \%82,7'sinin lisans eğitim düzeyinde olduğu; \%27,1'inin $6000 \mathrm{TL}$ ve üzerinde gelire sahip olduğu ve \%42,5' inin 4-6 yıl arasında iş tecrübesi olduğunu görmekteyiz.

\section{Hipotezlerin Test Edilmesi}

- H1: Şanlıurfa'daki bankalarda çalışan bireylerin işe yabancılaşma düzeyi, iş doyum düzeyi ve tükenmişlik düzeyleri arasında anlamlı bir ilişki vardır.

- H1a: Şanlıurfa'daki bankalarda çalışan bireylerin işe yabancilaşma düzeyi ve iş doyum düzeyi arasında anlamlı bir ilişki vardır.

- H1b: Şanlıurfa'daki bankalarda çalışan bireylerin işe yabanclaşma düzeyi ve tükenmişlik düzeyleri arasında anlamlı bir ilişki vardır.

- H1c: Şanlıurfa'daki bankalarda çalışan bireylerin iş doyum düzeyi ve tükenmişlik düzeyleri ve tükenmişlik düzeyleri arasında anlamlı bir ilişki vardır.

Tablo 9. İşe Yabancılaşma, İş Doyumu ve Tükenmişslik Düzeyi Arasındaki İlişkiyi Belirlemeye Yönelik Spearman Korelasyon Analizi Sonucu

\begin{tabular}{|c|c|c|c|c|}
\hline & & İșe Ya & İş Doyumu & $\begin{array}{l}\text { Tükenmişlik } \\
\text { Sendromu }\end{array}$ \\
\hline \multirow[t]{9}{*}{ Spearman's rho } & \multirow[t]{3}{*}{ İşe Yabancılaşma } & Correlation Coefficient 1,000 & $-401^{* *}$ &, $553^{* *}$ \\
\hline & & Sig. (2-tailed) & ,000 & 000 \\
\hline & & 214 & 214 & 214 \\
\hline & \multirow[t]{3}{*}{ İş Doyumu } & Correlation Coefficient,$- 401^{*}$ & 1,000 & $-452^{* *}$ \\
\hline & & Sig. (2-tailed) & . & 000 \\
\hline & & 214 & 214 & 214 \\
\hline & \multirow{3}{*}{$\begin{array}{l}\text { Tükenmişlik Sen } \\
\text { romu }\end{array}$} & 1-Correlation Coefficient , $553^{* *}$ &,$- 452^{* *}$ & 1,000 \\
\hline & & Sig. (2-tailed) & ,000 & \\
\hline & & $\mathrm{N}$ & 214 & 214 \\
\hline
\end{tabular}

**. Korelasyon 0.01 düzeyinde önemlidir (2 kuyruklu).

Katılımcıların işe yabancılaşma, iş doyumu ve tükenmişlik düzeyleri arasındaki ilişkiyi belirlemek için yapılan spearman korelasyon analizi sonucunda işe yabancılaşma ve iş doyumu arasındaki ilişkiden elde edilen sig. (p) değeri ,000'dır. $\mathrm{P}<, 05$ koşulunu sağladığı için bu iki değişken arasında anlamlı bir ilişki olduğu sonucu elde edilmiştir. Korelasyon katsayısı yani rho 0,00-0,25 arasında ise çok zayıf, 0,26-0,49 arasında ise düşük, 0,50- 0,69 arasinda ise orta, 0,70-0,89 arasında ise güçlü ve 0,90-1,00 arasında ise çok güçlü bir ilişki olduğu yorumu yapılabilir (Arslan, 2018:108; Küçük, Arslan ve Nur, 
2018:53; Nur, Arslan ve Küçük, 2020:18). Korelasyon katsayısı (rho) -,401 olmasından dolayı bu iki değişken arasında negatif ve düşük bir ilişki olduğu sonucuna varılmaktadır. Yani işe yabanclaşma düzeyi arttıkça iş doyumu düzeyi azalmaktadır. İşe yabancılaşma ve tükenmişlik düzeyleri arasındaki ilişkiden elde edilen sig. (p) değeri ,000'dır. $\mathrm{P}<, 05$ koşulunu sağladığı için bu iki değişken arasında anlamlı bir ilişki olduğu sonucu elde edilmiştir. Korelasyon katsayısı (rho),553 olmasından dolayı aralarında pozitif ve orta bir ilişki olduğu sonucuna varılmaktadır. Yani işe yabancılaşma arttıkça tükenmişlik düzeyi de artmaktadır. İş doyumu ve tükenmişlik düzeyi arasındaki ilişkiden elde edilen sig. (p) değeri ,000'dır $\mathrm{P}<, 05$ koşulunu sağladığı için bu iki değişken arasında anlamlı bir ilişki olduğu sonucu elde edilmiştir. Korelasyon katsayısı (rho) -,452 olmasından dolayı aralarında negatif ve düşük bir ilişki olduğu sonucuna varılmaktadır. İş doyumu arttıkça tükenmişlik düzeyi azalmaktadır. H1, H1a, H1b ve H1c hipotezleri desteklendi.

\section{Sonuç ve Öneriler}

Bu çalışmanın amacı, Şanlıurfa'da faaliyet gösteren bankalarda çalışan bireylerin işe yabancılaşma düzeyi, iş doyumu düzeyi ve tükenmişlik düzeyi arasındaki ilişkiyi belirlemektir. Bu amaçla hazırlanan anket online olarak Şanl1urfa' daki bankalarda çalışan 214 bireye gönüllülük esasına göre uygulanmıştir.

Çalışmada verilerin normal dağılımlı olup olmadığına yönelik yapılan analizler sonucunda verilerin normal dağ 1 lım göstermediği belirlenmiştir. Çalışmada yer alan işe yabancılaşma ölçeği, iş doyum ölçeği ve tükenmişlik sendromu ölçeklerine güvenirliliklerini belirlemek için Cronbach Alpha Analizi uygulanmıştır. Analiz sonucunda, çalışmada kullanılan ölçeklerin güvenilirliğinin yüksek olduğu tespit edilmiştir. Ayrıca çalışmada yer alan ölçeklere ilişkin açılayıcı faktör analizi yapılarak yapı geçerliliği test edilmiştir. Yapılan faktör analizi sonucunda, işe yabancı ölçeğindeki ifadelerin beş boyutta, iş doyumu ölçeğindeki ifadelerin tek boyutta ve tükenmişlik sendromu ölçeğindeki ifadelerin ise üç boyutta toplandığı belirlenmiştir.

Araştırmaya katılan katılımcıların demografik özelliklerine ilişkin frekans analizi yapılmıştır. Analiz sonucunda araştırmaya konu olan banka çalışanlarının \%52,8' i kadın \%47,2'si erkek; \%76,2'si evli ve \%23,8' i bekar bireylerden 
oluştuğu tespit edilmiştir. Katılımcıların \%69,2' $\operatorname{sinin} 29-38$ yaş aralığında olduğu; \%82,7'sinin lisans eğitim düzeyinde olduğu; \%27,1'inin 6000 TL ve üzerinde gelire sahip olduğu ve $\% 42,5$ 'inin 4-6 yıl arasında iş tecrübesi olduğu belirlenmiştir.

Katılımcıların işe yabancılaşma, iş doyumu ve tükenmişlik düzeyleri arasındaki ilişkiyi belirlemek için yapılan spearman korelasyon analizi sonucunda işe yabancılaşma ve iş doyumu arasında negatif ve düşük bir ilişki olduğu sonucu elde edilmiştir. Yani işe yabancılaşma düzeyi arttıkça iş doyumu düzeyi azalmaktadır. İşe yabancılaşma ve tükenmişlik düzeyleri arasında pozitif ve orta bir ilişki olduğu sonucuna varılmıştır. Yani işe yabanc1laşma arttıkça tükenmişlik düzeyi de artmaktadır. İş doyumu ve tükenmişlik düzeyi arasında negatif ve düşük bir ilişki olduğu sonucuna ulaşılmıştır. İş doyumu arttıkça tükenmişlik düzeyi azalmaktadır. Araştırma amacı doğrultusunda belirlenen $\mathrm{H1}$, H1a, H1b ve H1c hipotezleri desteklenmiştir.

Literatür incelendiğinde İşe Yabancılaşma, İş Doyumu ve Tükenmişlik kavramları tek tek ya da kavramlararası ikili ilişki veya etkiyi araştırma amaçlı çalışmalar yapılmıştır. Söz konusu üç kavram arasındaki ilişkiyi araştırmak amacıyla yapılan bu çalışma literatüre katkı sağlayacaktır.

Yapılan bu çalışma ile bundan sonra yapacakları çalışmalarda akademisyenlere rehberlik edilmeye ve karar verici konumunda bulunan banka yöneticilerine uygulayacakları stratejilerde yardımcı olmaya çalışılmıştır. Banka çalışanları üzerine yapılan bu çalışma daha geniş kitlelere ve farklı sektörlerde çalışanları kapsayacak şekilde yapılabilir. 


\title{
EXTENDED ABSTRACT
}

\section{The Relationship Between Job Satisfaction, Alienation And Fatigue In Bank Employees}

\author{
Kasım Kaya \\ Harran University
}

In rapidly changing world, the struggle to survive under the changing conditions is an indispensable systematic order, although it is frightening for everyone in the world. Undoubtedly, people are the most affected by this change. The fact that the human phenomenon is affected means that other beings existing in the order are affected. The result of this interaction brings along many material and spiritual changes. The concepts of job alienation, job satisfaction and fatigue can be counted as the effects of these changes.

Work alienation is the return of a person to his own essence for various reasons. In short, it is an expression of loneliness. It refers to the alienation of a person by moving away from his work and immediate environment. It is the conflict with one's own existence while performing the task. The fact that he has to work while his own existence accepts loneliness causes him to find his job meaningless. Job satisfaction is the summary of the proportional relationship between the job in which the individual is working and his own emotional thoughts. The fact that the individual likes his job is an indication of his job satisfaction. The concept of job satisfaction is an emotional concept, so emotion is important. The evaluation of feelings and feelings as a whole, and the person's physical and mental well-being is an expression of mental job satisfaction. Fatigue is a kind of sick mood. It makes a man feeling unhappy, restless, exhausted, bored and helpless. Fatigue is a psychology where all resources are consumed personally, life energy is exhausted and it gives a belief that nothing can improve no matter whatever he does. Along with psychological symptoms; various pains such as insomnia problems and headaches also accompany them.

This study was carried out to reveal the relationship between job alienation, job satisfaction and fatigue of individuals working in banks operating in Şanlıurfa. Due to limitations such as time, cost and data aging, the data were sampled. The main body of the research covers individuals working in banks 
in Şanlıurfa. Online survey method and convenience sampling method were used for data collection. The surveys were applied on a voluntary basis to 214 individuals working at banks in Şanlıurfa between 15.06.2020 and 15.08.2020. The primary data required for the research were collected by applying the survey method. The questionnaire prepared for the research consists of four parts. In the first part, there is a 24-item job alienation scale used by Çevik (2019) in the study titled "The Effect of Organizational Health on Work Alienation An Application in Kahramanmaraş Steel Mills". In the second part, there is a 14-item job satisfaction scale used in the study titled "The Effect of Job Satisfaction and Job Satisfaction among Bank Employees on Organizational Commitment" by Orhaner Gündüz (2016). In the third part, the 22-item Maslach Fatigue Scale developed by Maslach and Jackson (1981) is included. In the fourth part, there are 6 demographic factor questions measuring gender, marital status, age, average income level, education level and total working time. Scales were measured with a 5-point Likert.

The data obtained in the study were analysed using the SPSS (Statistical Package for Social Sciences) for Windows 25.0 program. Descriptive statistical methods (number, percentage, average) were used while evaluating the data. Compliance with normal distribution in the data can be examined with the Q-Q Plot drawing. In addition, the normal distribution of the data used depends on the skewness and kurtosis values between \pm 3 . Normal distribution was checked with congruence normality tests and kurtosis skewness values. When the data were evaluated, it was found that the normal distribution assumption was not fulfilled. Since the normal distribution assumption was not fulfilled in the analysis of the data, Spearman correlation analysis was performed to examine the relationship in continuous data. In order for the tests and results to be reliable, the scales must be reliable. In this context, the reliability of scales and sub-dimensions was examined with Cronbach Alpha. In addition, explanatory factor analysis of the scales was performed and the construct validity was tested.

In the study, it was determined that the data did not show normal distribution as a result of the analysis made to determine whether the data were normally distributed. Cronbach's Alpha Analysis was applied to determine the reliability of the job alienation scale, job satisfaction scale and fatigue syndrome scales in the study. As a result of the analysis, it was found that the scales used in the study had high reliability. In addition, explanatory factor 
analysis was performed for the scales in the study and the construct validity was tested. As a result of the factor analysis, it was determined that the statements in the foreigner to work scale were collected in five dimensions, the statements in the job satisfaction scale in one dimension, and the statements in the fatigue syndrome scale in three dimensions.

Frequency analysis of the demographic characteristics of the participants in the study was made. As a result of the analysis, $52.8 \%$ of the bank employees subject to the study are women, $47.2 \%$ are men; and it was determined that $76.2 \%$ were married and $23.8 \%$ were single individuals. $69.2 \%$ of the participants are in the $29-38$ age range; $82.7 \%$ of them are at the undergraduate education level; and it was determined that $27.1 \%$ had an income of $6000 \mathrm{TL}$ and above and $42.5 \%$ had $4-6$ years of work experience.

As a result of the spearman correlation analysis conducted to determine the relationship between job alienation, job satisfaction and fatigue levels of the participants, it was found that there was a negative and low relationship between job alienation and job satisfaction. In other words, as the level of alienation increases, the level of job satisfaction decreases. It was concluded that there is a positive and moderate relationship between job alienation and fatigue levels. In other words, as job alienation increases, the level of fatigue increases. It was concluded that there is a negative and low relationship between job satisfaction and burnout level. As job satisfaction increases, the level of fatigue decreases.

With this study, it will be tried to guide academics and bank managers in the strategies they will implement.

\section{Kaynakça / References}

Arslan, B. (2018). Marka aşkının tüketicilerin rasyonel olmayan satın alma davranışna etkisi: hazır giyim sektöründe bir uygulama. Journal of Strategic Research in Social Science, 8 (2), 97-118

Arslan, B., ve Nur, E. (2018). Teknolojinin yeni çocuğu: K kuşağı. Avrasya Uluslararası Araştırmalar Dergisi, 6(15), 329-347.

Atiker, E. (1998). Modernizm ve kitle toplumu. Vadi.

Aytaç, Ö. (2005). Modern bürokrasiler ve yabancılaşma ethosu. Fırat Üniversitesi Sosyal Bilimler Dergisi, 320, 321-326 
Bademci, V. (2001). Türkiye' deki okullar ne işe yarar. Konferans. Düzenleyen: Ankara Türk Telekom Anadolu Teknik L. Ankara: Başkent Öğretmenevi Konferans Salonu, 9 .

Başaran, İ. E. (2008). Örgütsel davranış: İnsanın üretim gücü. Ekinoks Eğitim Danışmanlik.

Çakır, Ö. (2006). Ücret adaletinin iş davranışları üzerindeki etkisi. Kamu-iş.

Çalışkan, Z. (2005). İş tatmini: Malatya'da sağlık kuruluşları üzerine bir uygulama. Fırat Üniversitesi Doğu Araştırmalan Dergisi, 4(1), 9-18

Çam, O. (1992). Tükenmişlik envanterinin geçerlik ve güvenirliğinin araştırılması. VII. Ulusal Psikoloji Kongresi Bilimsel Çalışmalan El Kitabı, 155-166.

Dinçer, Ö. (1998). Stratejik yönetim ve işletme politikası (5. Bask1). İstanbul: Beta Basim Yayım Dă̆ıtım.

Ehtiyar, R., ve Yanardağ, M. (2008). Organizational silence: A survey on employees working in a chain hotel. Tourism and Hospitality Management, 14(1), 51-68

Erdoğan, İ. (1996). İşletme yönetiminde örgütsel davranış. İstanbul Üniversitesi İşletme Fakültesi.

Erkmen, T., ve Şencan, H. (1994). Örgüt kültürünün iş doyumu üzerindeki etkisinin otomotiv sanayide faaliyet gösteren farklı büyüklükteki iki işletmede araştırılması. İ̈̈ İşletme Fakültesi Dergisi, 23(2), 107-125

Eyuboğlu, İ. Z. (1995). Türk dilinin etimoloji sözlüğ̈̈. Sosyal yayınlar.

Farber, B. A. (1984). Stress and burnout in suburban teachers. The Journal of Educational Research, 77(6), 325-331

Gençay, Ö. A. (2007). Beden eğitimi öğretmenlerinin iş doyumu ve mesleki tükenmişliklerinin bazı değişkenler açısından incelenmesi. Kastamonu Eğitim Dergisi, 15(2), 765-780

Güçlü, N. (2003). Örgüt kültürü. Gazi Üniversitesi Sosyal Bilimler Dergisi, 23(2), 61-85.

Günsal, E. (2010). Algılanan örgütsel adalet ile örgütsel yabancılaşma arasındaki ilişki ve bir araştırma

Izgar, H. (2003). Çalışanlarda Stres ve Tükenmişlik. Endüstri ve Örgüt Psikolojisi, Ed: Hüseyin Izgar, Eğitim Kitabevi Yayınları, Konya.

Kaçmaz, N. (2005). Tükenmişlik (burnout) sendromu. İstanbul Tıp Fakültesi Dergisi, 68(1), 29-32

Keser, A. (2006). Çağrı merkezi çalışanlarında iş yükü düzeyi ile iş doyumu ilişkisinin araştırılması

Kolasa, J. B. (1969). İşletmeler İçin Davranış Bilimlerine Giriş, Çev. Kemal Tosun ve Diğ., İşletme İktisadı Enstitüsü Yayınları, (42). 
Korman, A. K., Akhun, İ., ve Alkan, C. (1978). Endüstriyel ve organizasyonel psikoloji. Milli Eğitim Bakanlığı.

Küçük, F., Arslan, B., ve Nur, E.. (2018). Hizmet kalitesi algısı ile memnuniyet düzeyi arasındaki ilişki: Harran Üniversitesi öğrencileri üzerine bir uygulama. Econharran Harran Üniversitesi Ï̈BF Dergisi, 2(2), 40-56.

Levinson, H. (1996). Burnout. Harvard Business Review. July-August, 153-161.

Maslach, C., ve Jackson, S. E. (1981). The measurement of experienced burnout. Journal of organizational behavior, 2(2), 99-113.

Mottaz, C. J. (1981). Some determinants of work alienation. Sociological Quarterly, 22(4), 515-529.

Nur, E., Arslan, B. ve Küçük F. (2020). Teknoloji ve... Edi. Aztimur, H. ve Arslan, B., Bölüm Adı: Sanal Kaytarma Davranışları ile Çevrimiçi Satınalma Davranışları Arasındaki İlişki: Kadın Sağlık Çalışanlar Üzerine Ampirik Bir Çalışma. Litvanya: SRA Akademik Yayınlar.

Oshagbemi, T. (2000). Is length of service related to the level of job satisfaction?. International Journal of Social Economics.

Özler, n. d. e., ve Dirican, m. ö. Örgütlerde yabancılaşma ile tükenmişlik sendromu arasındaki ilişkiyi belirlemeye yönelik bir araştırma. Dumlupınar üniversitesi sosyal bilimler dergisi, (39).

Sevimli, F., ve İşcan, Ö. F. (2005). Bireysel ve iş ortamina ait etkenler açisindan iş doyumu. Ege Akademik Bakış Dergisi, 5(1), 55-64.

Sürgevil, O. (2006). Çalışma hayatında tükenmişlik sendromu: Tükenmişlikle mücadele teknikleri. Nobel Yayın.

Şimşek, H., Balay, R., veŞimşek, A. (2012). İlköğretim sınıf öğretmenlerinde mesleki yabancılaşma. Eğitim Bilimleri Araştırmalan Dergisi, 2(1), 53-72.

Şimşek, M.Ş., Çelik, A., Akgemci, T., ve Fettahlığlu, T. (2006). Örgütlerde yabanc1laşmanın yönetimi araştırması. Selçuk Üniversitesi Sosyal Bilimler Enstitüsü Dergisi , (15), 569-587.

Tekir, Ö., Çevik, C., Selma, A. R. I. K., ve Çetin, G. (2016). Sağlık çalışanlarının tükenmişlik, iş doyumu düzeyleri ve yaşam doyumunun incelenmesi. Kırıkale Üniversitesi Tıp Fakültesi Dergisi, 18(2), 51-63.

Torun, A. (1997). Stres ve Tükenmişlik, Endüstri ve Örgüt Psikolojisi. Baskı, Editör: Suna Tevrüz, Türk Psikologlar Derneği ve Kalder Derneği Ortak Yayını, İstanbul.

Turan, M., ve Parsak, G. (2011). Yabancılaşma ve iş tatmini ilişkisi: Bir devlet üniversitesi idari personeli üzerinde araştırma. Çukurova Üniversitesi Sosyal Bilimler Enstitüsü Dergisi, 20(2), 1-20. 
Tutar, H. (2004). İş yerinde psikolojik şiddet. Platin Yayınları.

Yalçın, İ., ve Koyuncu, S. C. (2014). Örgütsel Yabancılaşma Olgusunun İş Tatmini Üzerine Etkisi: Niğde İlinde Bir Araştırma. Karamanoğlu Mehmet Bey Üniversitesi Sosyal ve Ekonomik Araştırmalar Dergisi, 2014(1), 86-94.

\section{Kaynakça Bilgisi / Citation Information}

Kaya, K. (2021). Banka Çalışanlarında işe yabancılaşma, iş doyumu ve tükenmişlik arasındaki ilişki. OPUS-Uluslararası Toplum Araştırmalarn Dergisi, 17(37), 4510-4534. DOI: 10.26466/opus.821059 